\title{
APLIKASI PENGAJUAN KREDIT BERBASIS WEB PADA PT ADIRA QUANTUM MULTIFINANCE
}

\author{
Sity Aisyah ${ }^{1}$ \\ Nawang Kalbuana ${ }^{2}$ \\ Ipat Patmawati ${ }^{3}$ \\ e-mail :dryesha@gmail.com,nawang.kalbuana@gmail.com, \\ caem.nanas@gmail.com.
}

Diterima : 13 Desember 2011 / Disetujui : 22 Desember 2011

\begin{abstract}
ABSTRAKSI
PT. Adira Quantum Multifinance (PT. Adira) merupakan salah satu perusahaan yang bergerak dalam bidang penyelenggaraan dan pengembangan sektor bisnis pembiayaan yang berfokus pada pembiayaan barang elektronik, komputer dan furniture yang berkantor pusat di Jakarta dan membuka cabang di seluruh Indonesia termasuk di Tangerang Jl. Raya serpong KM 7 Pakulonan Serpong (Kompleks Sutera Niaga 1/65). Dalam aktivitas pengajuan kredit yang dilakukan antara pelanggan dan PT. Adira seringkali terjadi masalah diantaranya informasi mengenai disetujui atau tidaknya pengajuan kredit oleh pelanggan terlalu lama dikarenakan dalam proses pengajuan kredit tersebut masih menggunakan proses manual berupa pengisian beberapa formulir-formulir yang mana nantinya formulir tersebut akan di rekapitulasi setelah itu baru disampaikan ke pusat, sehingga menyebabkan informasi yang ditunggu oleh pelanggan tersebut lama. Disamping itu dengan proses yang masih manual, sering adanya kehilangan berkas dikarenakan banyaknya tumpukan pengajuan oleh pelanggan. Oleh karena itu, penulis mencoba mengusulkan suatu alternatif solusi untuk pemecahan masalah dengan merancang suatu sistem aplikasi berbasis web dalam pengajuan kredit. Diharapkan dengan adanya sistem ini akan memecahkan masalah yang dihadapi oleh PT. Adira dan menambah kepercayaan pelanggan terhadap PT. Adira.
\end{abstract}

Kata kunci :Pengajuan Kredit, Website.

1. Dosen Jurusan Komputerisasi Akuntansi, AMIK Raharja Informatika J1. Jend Sudirman No. 40 Modern Cikokol-Tangerang Telp. 5529692

2. Dosen Jurusan Komputerisasi Akuntansi, AMIK Raharja Informatika Jl. Jend Sudirman No. 40 Modern Cikokol-Tangerang Telp. 5529692

3. Mahasiswa Jurusan Komputerisasi Akuntansi, AMIK Raharja Informatika Jl. Jend Sudirman No. 40 Modern Cikokol-Tangerang Telp. 5529692 


\section{PENDAHULUAN}

Pada era sekarang ini kemajuan teknologi dan ilmu pengetahuan berkembang dengan sangat cepat di berbagai bidang kehidupan. Sehingga persaingan yang ada akan semakin ketat terutama dibidang teknologi informasi. Kalangan industri maupun instansi-instansi lainnya memerlukan suatu informasi yang cepat, data yang akurat dan keamanan data yang kuat. Internet yang berkembang pesat sekarang ini tentunya dapat mempermudah atau memaksimalkan penyampaian informasi dari satu pihak kepihak yang lain. Perkembangan dunia internet yang sangat pesat membuat banyak orang menghabiskan sebagian besar waktunya di depan perangkat yang terkoneksi dengan internet, mulai dari belajar, berbelanja dan bekerja semua dilakukan lewat dunia maya. Website merupakan salah satu layanan yang ditawarkan oleh internet diantara layanan-layanan lainnya. Website adalah homepage dimana homepage merupakan halaman awal sebuah domain.

PTAdira Quantum Multifinance merupakan sebuah perusahaan yang bergerak dibidang pembiayaan kredit elektronik selain motor terbesar di Indonesia yang berkantor pusat di Jakarta dan mempunyai cabang dibeberapa daerah. Dalam pengolahan data, masih menggunakan sistem manual khususnya dalam pengajuan kredit. Sehingga menyebabkan lamanya keputusan mengenai persetujuan kredit yang diajukan oleh pelanggan oleh PT Adira, hal ini menyebabkan kekecewaan pelanggan atas lamanya informasi yang ditunggu oleh pelanggan mengenai pengajuan kreditnya tersebut. Informasi tersebut lama dikarenakan proses dalam pengajuan kredit masih bersifat manual yaitu berupa formulir-formulir yang diisi oleh pelanggan kemudian dientri oleh petugas administrasi lalu dikirim ke pusat untuk ditinjau pengajuan kreditnya. Dalam proses pengajuan kredit tersebut sering terjadi masalah seperti data yang diisi tidak lengkap, hilangnya berkas karena banyaknya tumpukan formulir, dan lain-lain. Sehingga penulis menilai PT.Adira memerlukan suatu sistem informasi yang kuat didalam menghadapi persaingan dengan lembaga-lembaga lainnya yang sejenis dan untuk memberikan pelayanan yang maksimal kepada pelanggannya.Atas kendala tersebut, penulis memberikan solusi terhadap permasalahan yang ada yaitu dengan mendesain sistem informasi pengajuan kredit berbasis web yang akan digunakan untuk meningkatkan efisiensi kerja dan menghasilkan informasi yang akurat serta tepat waktu. Selain itu, dapat memberikan kepuasan bagi pelanggan sehingga tidak perlu menunggu lama dalam memperoleh hasil keputusan pengajuan kreditnya. 


\section{METODE PENELITIAN}

Metodologi adalah satuan metode-metode, prosedur-prosedur, konsepkonsep pekerjaan, aturan-aturan dan postulat-postulat yang digunakan oleh suatu ilmu pengetahuan, seni atau disiplin lainnya. Sedangkan metode adalah suatu cara / teknik yang sistematik untuk mengerjakan sesuatu. Penelitian ini menggunakan penelitian pendekatan kualitatif. Menurut Poerwandari (1998) penelitian kualitatif adalah penelitian yang menghasilkan dan mengolah data yang sifatnya deskriptif, seperti wawancara, catatan lapangan, gambar, foto rekaman video dan lain-lain. Dalam penelitian kualitatif perlu menekankan pada pentingnya kedekatan dengan orang-orang dan situasi penelitian, agar peneliti memperoleh pemahaman jelas tentang realitas dan kondisi kehidupan nyata (Patton dalam Poerwandari, 1998).

Adapun metodologi penelitian yang digunakan :

1. Metode Observasi (observation)

Menurut Nawawi \& Martini (1991) observasi adalah pengamatan dan pencatatan secara sistimatik terhadap unsur-unsur yang tampak dalam suatu gejala atau gejala-gejala dalam objek penelitian.

2. Metode Wawancara (Interview)

Menurut Prabowo (1996) wawancara adalah metode pengmbilan data dengan cara menanyakan sesuatu kepada seseorang responden, caranya adalah dengan bercakap-cakap secara tatap muka. Interview yang disebut juga wawancara atau kuesioner lisan adalah sebuah dialog yang dilakukan oleh pewawancara untuk memperoleh informasi dari terwawancara (Arikunto, 2002: 132).

3. Metode Studi Pustaka (Library Research)

Studi Pustaka merupakan metode pengumpulan data yang berasal daribukubuku literatur. Menurut Gorys Keraf (1997: 165) metode Studi pustakadapat dijabarkan sebagai berikut: Metode studi pustaka adalah metodepengumpulan data yang memanfaatkan buku atau literatur sebagai bahan referensi untuk memperoleh kesimpulan-kesimpulan atau pendapat para ahli dengan mendapatkan kesimpulan tersebut sebagai metode tersendiri.

\section{HASIL DAN PEMBAHASAN}

\section{Pengertian Kredit}

Pengertian Kredit menurut Kasmir (2003:72) mengatakan bahwa: 
"Dalam bahasa latin kredit disebut credere yang artinya percaya. Maksudnya si pemberi kredit percaya kepada si penerima kredit yang disalurkan pasti akan dikembalikan sesuai perjanjian. Sedangkan bagi si penerima kredit berarti menerima kepercayaan, sehingga mempunyai kewajiban untuk membayar kembali pinjaman tersebut sesuai dengan jangka waktunya".

\section{Klasifikasi Kredit}

Menurut Wijaya dan Wirasasmita (2000:75) kredit dapat diklasifikasikan menjadi :

a. Kredit menurut tujuan penggunaannya Yaitu : kredit konsumtif dan kredit produktif (kredit investasi, kredit modal kerja).

b. Kredit dalam pengalihan hak materinya

Yaitu : kredit dalam bentuk uang, dan kredit bukan dalam bentuk uang.

c. Kredit menurut jangka waktunya

Yaitu : kredit jangka pendek (selama-lamanya satu tahun) sebagai modal kerja, kredit jangka menengah (selama-lamanya 1-3 tahun) sebagai modal kerja dan investasi yang jumlahnya kecil, kredit jangka panjang (selama-lamanya 3-5 tahun) sebagai investasi besar.

d. Kredit menurut cara penggunaannya

Yaitu : kredit tunai dan jredit bukan tunai (garansi bank/jaminan/LC).

e. Kredit dilihat dari sektor ekonomi

Yaitu : kredit yang dilihat dari sektor pertanian, kredit sektor pertambangan, perindustrian, listrik, gas, air, dan sektor konstruksi.

\section{Pengertian Website}

Website atau situs web merupakan tempat penyimpanan data dan informasi berdasarkan topik tertentu. Diumpamakan situs web ini adalah sebuah buku yang berisi topik tertentu. Website juga merupakan kumpulan dari halaman-halaman web yang saling berkaitan di dalam web tersebut (Budi Irawan, 2005).

Website juga dapat diartikan sebagai kumpulan halaman yang menampilkan informasi data teks, data gambar diam atau gerak, data animasi, suara, video, dan atau gabungan dari semuanya, baik yang bersifat statis maupun dinamis yang membentuk satu rangkaian bangunan yang saling terkait dimana masing-masing dihubungkan dengan jaringan-jaringan halaman (hyperlink). Bersifat statis apabila isi informasi website tetap, jarang berubah, dan isi informasinya searah hanya dari pemilik website. Bersifat dinamis apabila isi informasi website selalu berubah-ubah, 
dan isi informasinya interaktif dua arah berasal dari pemilik serta pengguna website. Contoh website statis adalah berisi profil perusahaan, sedangkan website dinamis adalah seperti friendster, multiply, dan lain-lain. Dalam sisi pengembangannya, website statis hanya bisa diupdate oleh pemiliknya saja, sedangkan website dinamis bisa diupdate oleh pengguna maupun pemilik.

\section{Analisis dan Perancangan Sistem}

Metode yang digunakan dalam menganalisis sistem ini adalah System Develoment Life Cycle SDLC. Dan struktur metodologi SDLC dalam pengembangan sistem informasi berbasis web yaitu:

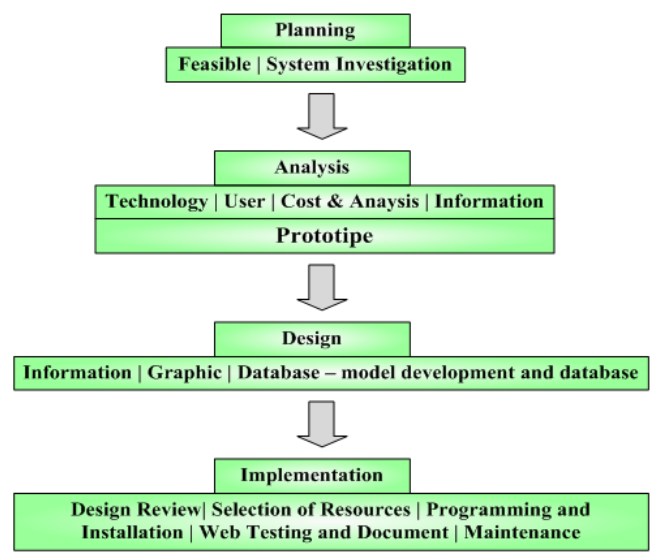

Gambar 1. Metode SDLC

Tahap - tahap SDLC dalam pembangunan sistem informasi web :

1. Perencanaan

Planning (perencanaan) adalah feasibility dan wawancara, observasi, quesioner. Jika pada tahap feasibility hasilnya baik maka langsung ketahap investigasi dan diberi form kepada client untuk mencatat kebutuhan client. Dalam sistem investigasi, dapat berupa wawancara, kuosiener atau observasi. Dalam tahap ini hal yang pertama dilakukan adalah memberikan form ke user yang digunakan untuk mengetahui permintaan user.

2. Analisis

a. Analisa Teknologi.Menganalisis teknologi apa yang digunakan pemilik desain web seperti menggunakan desain grafis maka memerlukan teknologi seperti 
Adobe Photoshop, Macromedia Flash, Dreamweaver. Memerlukan data penyimpanan secara informasi produk, Informasi Berita digunakan database seperti Mysql.

b. Analisa informasi. Mengenai informasi data yang akan menjadi data tetap dan data dinamis, kategori informasi data tetap adalah : profil perusahaan, visi dan misi, sejarah perusahaan, latar belakang perusahaan. Informasi dinamis adalah informasi yang selalu berubah dalam setiap periodik dapat setiap hari atau setiap jam.

c. Analisa User. Mengkatogorikan user yang digunakan dalam sistem informasi web. User yang sudah memahami dan yang belum memahami.

d. Analisa Biaya dan Resiko. Dalam tahap ini diperhitungkan biaya yang akan dikeluarkan seperti biaya maintenance (membayar domain ke ISP) atau biaya kirim ke user. Resiko yang terjadi adalah tidak sampainya produk ke user atau penipuan dari user.

Dalam tahap analisa menggunakan metoda prototype yang akan dilakukan iterasi oleh user, dan penggunaan dokumen disetiap iterasi untuk memudahkan dalam pengembangan kemajuan yang telah dilakukan oleh user. Prototype adalah proses membangun sebuah sistem dalam sebuah model. Dalam pengertian sistem informasi prototype digunakan untuk membantu sistem desain yang akan dibangun sistem informasi secara intitusi dan mudah diubah untuk end user, prototype merupakan bagian dari proses iterative phase analisa dari metodologi SDLC.

\section{Desain}

a. Desain Informasi. Dalam tahap ini dimodelkan informasi link dari setiap halaman, jika dalam sistem tersebut terdapat database maka digunakan tahap development dan database disain.

b. Desain Grafis. Dalam tahap ini disesuaikan dari warna, layout, gambar dan grafis.

c. Database Application

d. Model Development Database Design PHP Library Development. Tahap untuk memodelkan seluruh peruses yang ada, seperti peruses penyimpanan data, update artikel, dan menampilkan data dari database.

4. Implementasi

a. Penulisan Program dan Instalasi. Merupakan tahap penulisan program yang telah dianalisis dan didesain semua maka program yang digunakan adalah PHP dan database yang digunakan MySql. 
b. Desain Review. Dalam tahap ini tidak hanya menguji desain yang digunakan namun menguji semua sistem yang telah diterapkan seperti tidak ada lokasi link, image yang salah, pengujian sistem seperti penyimpanan data, update artikel dan lain-lain.

c. Pemilihan Sumber daya Hardware dan Software. Dalam tahap ini software dan hardware digunakan untuk web server.

d. Pengujian Web dan Dokumen Web. Menguji web dengan berbagai teknologi browser yang ada, serta pemeriksaan dokumen web.

Berdasarkan hasil analisis dalam bentuk uraian masalah, kebutuhan sistem, dan usulan yang berkaitan dengan informasi jurnal, maka dapat didefinisikan uraian analisis yang dibutuhkan:

1. Kebutuhan :Aplikasi pengajuan kredit

Masalah : Untuk merekap dokumen customer yang terkomputerisasi

dikarenakan masih menggunakan proses catat mencatat dalam pengisian aplikasi pengajuan kredit.

Usulan : Merancang aplikasi pengajuan kredit yang user friendly, bisa diakses oleh siapa saja, digunakan dimana saja, kapan saja dan tanpa harus mengeluarkan biaya yang sangat mahal.

2. Kebutuhan :Database

Masalah : Dibutuhkan database untuk menyimpan data-data customer, informasi kredit, dan lain-lain.

Usulan : Dibuat database dinamis untuk menyimpan data-data customer.

\section{Use Case Diagram}

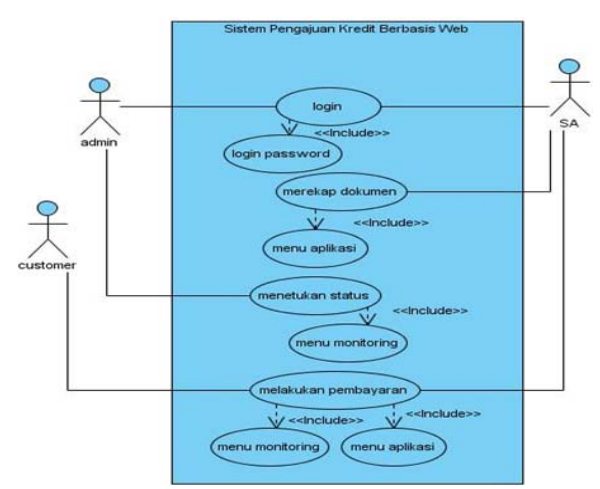

Gambar 2. Use case diagram usulan 
Berdasarkan gambar 2 di atas dapat dijelaskan bahwa :

1. Use Case Login

- Use Case :Login

- Primary Actor : Admin,SA(Sahabat Adira)

- Precondition : Admin harus melakukan login ketika ia ingin mengetahui pengajuan kredit yang ada di merchant, SA (Sahabat Adira) melakukan login ketika akan mengisi aplikasi yang diserahkan customer pada saat pengajuan kredit.

2. Use Case Merekap Dokumen

- Use Case : Merekap Dokumen

- Primary Actor : SA(Sahabat Adira)

- Precondition :SA (sahabat adira) melakukan rekap dokumen setelah di isi lengkap oleh customer, dengan menyimpannya di menu aplikasi.

3. Use Case Menentukan Status

- Use case :Menentukan Status

- Primary Actor :Admin

- Precondition : Setelah SA(Sahabat Adira) menyimpan data customer di menu aplikasi, selanjutnya admin bisa melihat langsung di menu monitoring dan kemudian menganalisis untuk menentukan status customer disetujui atau tidak disetujui oleh pihak manajemen.

4. Use Case Melakukan Pembayaran

- Use Case :Melakukan Pembayaran

- Primary Actor :SA (Sahabat adira) dan Customer

- Precondition : customer datang langsung dan memperlihatkan sms yang telah dikirim oleh pihak Adira, selanjutnya SA (Sahabat Adira) memeriksa status di menu monitoring dan mencetak form pembiayaan dan barang untuk melakukan pembayaran di merchant.

\section{Rancangan Arsitektur Sistem Informasi Pengajuan Kredit (SIPK)}




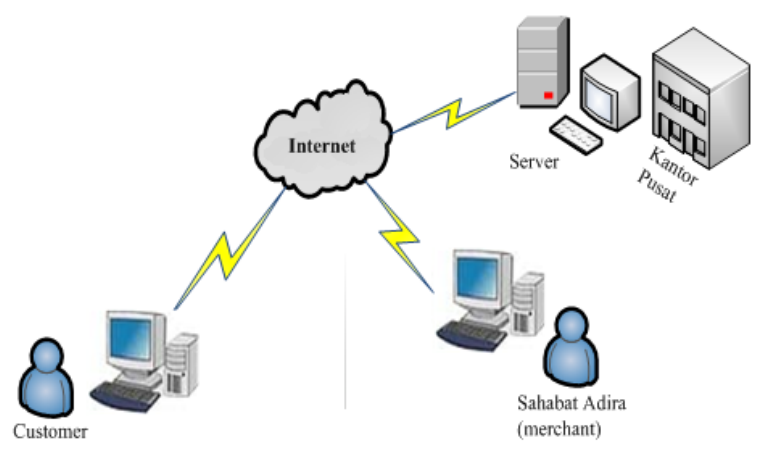

Gambar 3. Arsitektur Jaringan SIPK

Dari gambar di atasdapat dijelaskan bahwa dalam membangun arsitektur jaringan sistem informasi pengajuan kredit ini customer dapat mengajukan kredit dengan membuka website PT.Adira lalu mengisi formulir permohonan kredit dengan mengisi terlebih dahulu daerah dimana Sahabat Adira berada, setelah itu Sahabat Adira akan menerima pengajuan dari customer dengan membuka aplikasi SIPK setelah itu akan ditindaklanjuti dengan mengirimkan pesan kepada customer untuk dapat menyerahkan berkas-berkas yang dibutuhkan dalam pengajuan kredit. Setelah dianalisis dan dinyatakan layak, Sahabat Adira mengirimkan laporan kepada Kantor Pusat untuk meminta persetujuan kredit tersebut, jika di setujui Pusat akan memberikan status 1 (yang artinya setuju) dan customer dapat melihat langsung secara online pada SIPK mengenai pengajuan kreditnya.

\section{Rancangan Class Diagram}

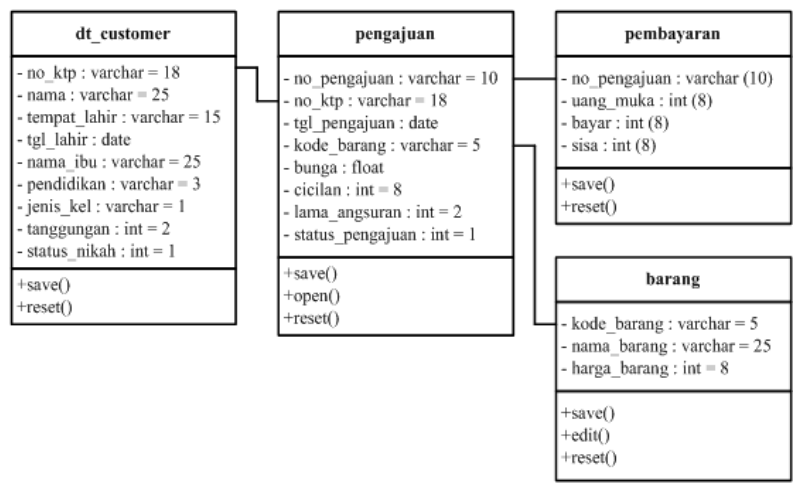

Gambar 4. Rancangan Class Diagram 
Pada class diagram di atas terdiri dari 4 (empat) tabel yaitu dt_customer, pengajuan, pembayaran dan barang, dimana masing-masing tabel saling berhubungan satu dengan yang lain.

\section{Tampilan Sistem Informasi Pengajuan kredit (SIPK)}

\section{Tampilan Menu Home}

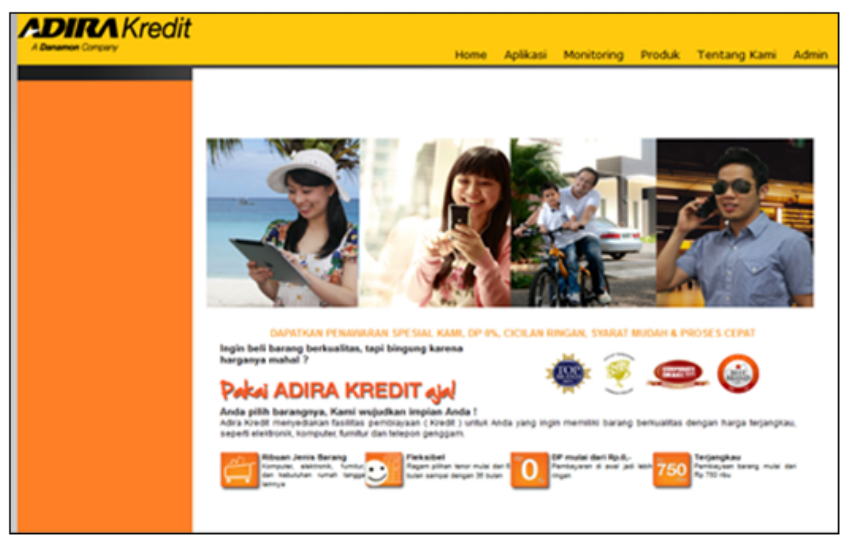

Gambar 5. Tampilan Home

Gambar diatas merupakan tampilan utama web PT. Adira dimana SA(Sahabat Adira dapat merekap dokumen customer dan mengetahui status yang telah diproses oleh pihak analis Adira) serta dapat mengetahui event-event yang sedang berlangsung.

\section{Tampilan Pengisian Aplikasi Data Pribadi}

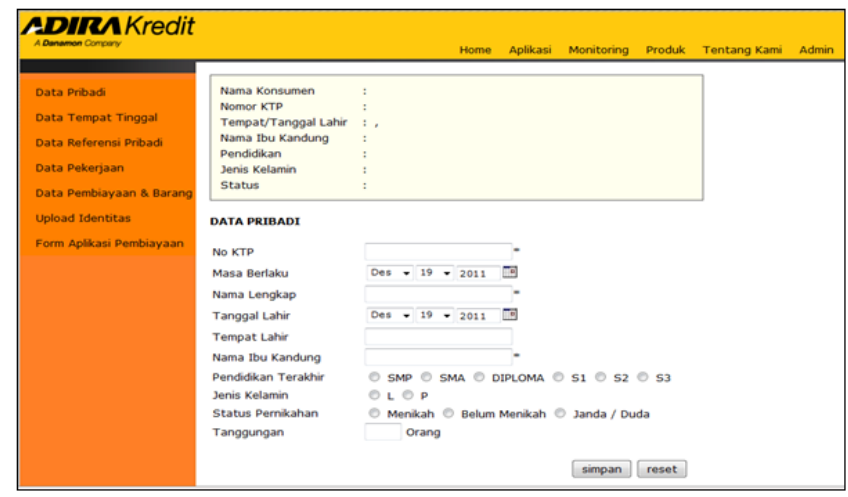

Gambar 6. Pengisian Aplikasi Data Pribadi 
Gambar diatas merupakan data pribadi customer dari menu aplikasi, yang di diisi oleh SA (Sahabat Adira) dimana data diperoleh dari dokumen yang telah diisi pada saat pengajuan.

\section{Tampilan Aplikasi Data Tempat Tinggal}

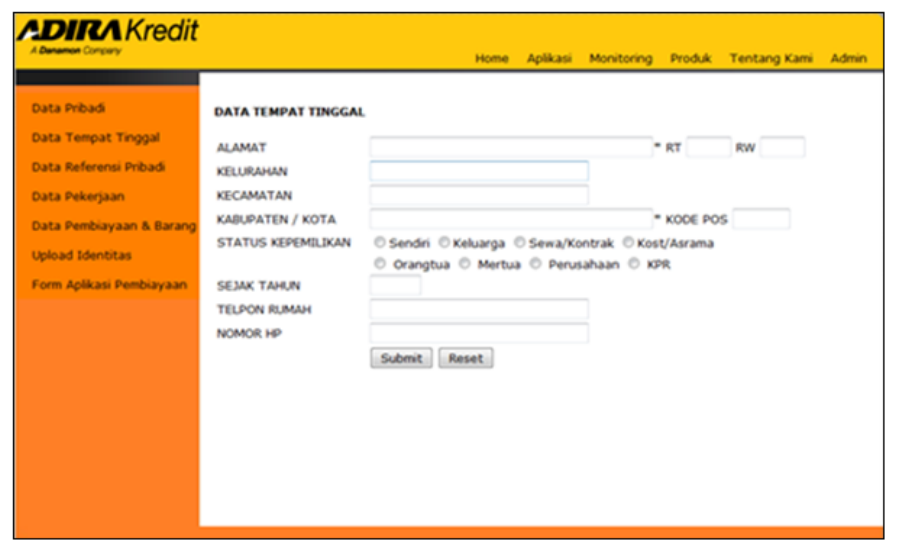

Gambar 7. Pengisian Aplikasi Tempat Tinggal

Gambar diatas merupakan data tempat tinggal customer, dari menu aplikasi yang diisi oleh SA (Sahabat Adira) diperoleh dari dokumen yang diserahkan customer pada saat pengajuan.

\section{Tampilan Aplikasi Data Referensi Pribadi}

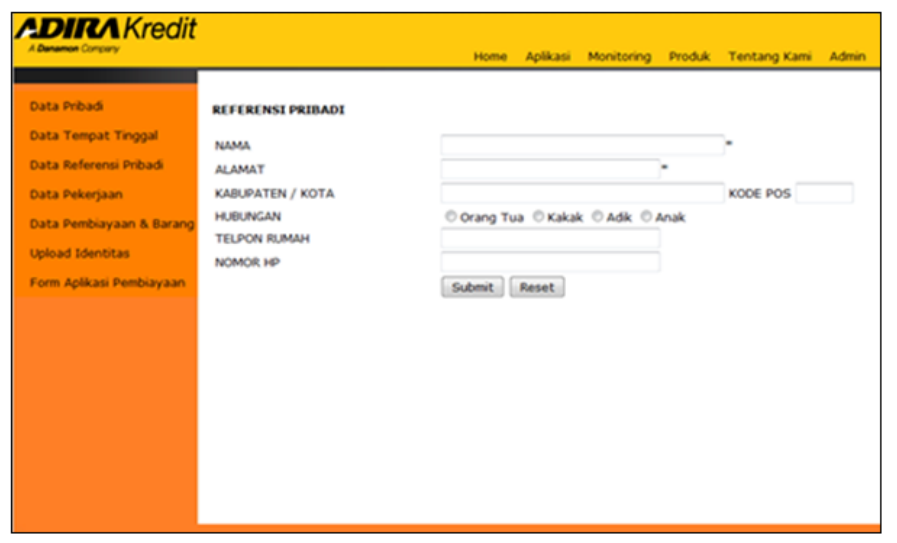

Gambar 8. Pengisian Aplikasi Data Referensi Pribadi 
Gambar diatas merupakan data referensi pribadi customer (keluarga terdekat yang dapat dihubungi untuk dapat dimintai keterangan), dari menu aplikasi yang diisi oleh SA (Sahabat Adira) diperoleh dari dokumen yang diserahkan customer pada saat pengajuan.

\section{Tampilan Aplikasi Data Pekerjaan}

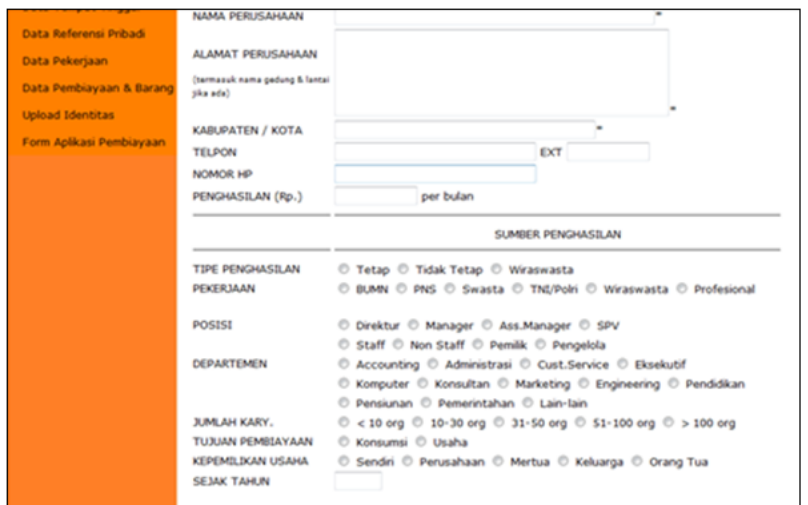

Gambar 9. Pengisian Aplikasi Data Pekerjaan

Gambar diatas merupakan data pekerjaan customer, dari menu aplikasi yang diisi oleh SA (Sahabat Adira) diperoleh dari dokumen yang diserahkan customer pada saat pengajuan.

\section{Tampilan Aplikasi Data Pembiayaan dan Barang}

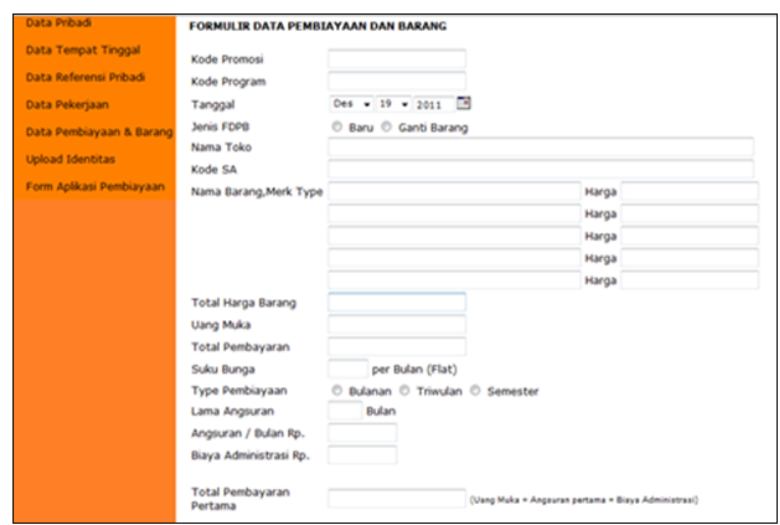

Gambar 10. Pengisian Aplikasi Data Pembiayaan dan Barang 
Gambar diatas merupakan data pembiayaan dan barang customer (di mana customer mengkredit barang dari Adira sesuai lama angsuran) dari menu aplikasi yang diisi oleh SA (Sahabat Adira) diperoleh dari dokumen yang diserahkan customer pada saat pengajuan.

\section{Tampilan Aplikasi Upload Identitas}

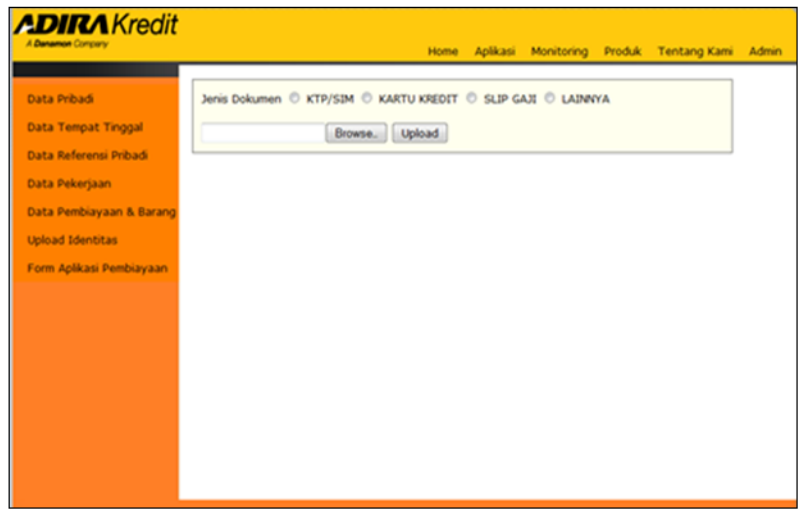

Gambar 11. Pengisian Aplikasi Upload Identitas

Gambar diatas merupakan upload identitas customer (di mana customer pada saat pengajuan memakai identitas ktp dan sebagainya) dari menu aplikasi yang diisi oleh SA (Sahabat Adira) diperoleh dari dokumen yang diserahkan customer pada saat pengajuan.

\section{Tampilan Aplikasi Pembiayaan}

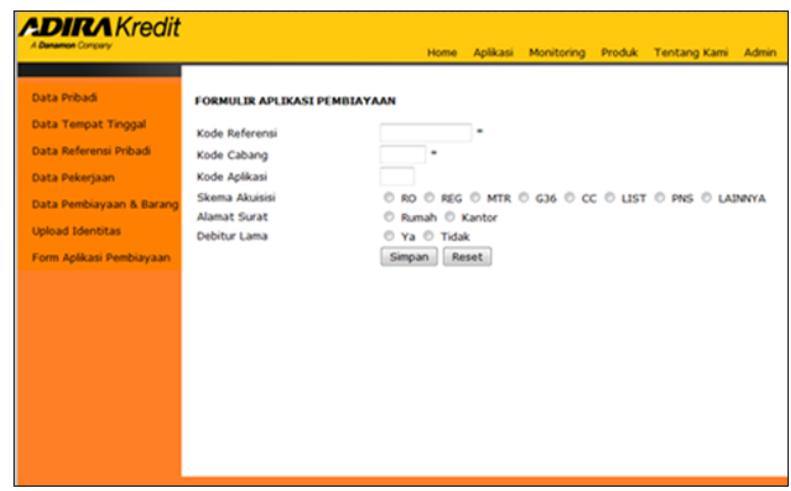

Gambar 12. Pengisian Aplikasi Pembiayaan 
Gambar diatas merupakan form aplikasi pembiayaan (untuk pengiriman alamat surat menyurat) dari menu aplikasi yang diisi oleh SA (Sahabat Adira) diperoleh dari dokumen yang diserahkan customer pada saat pengajuan.

\section{KESIMPULAN}

1. Sistem pengajuan kredit pada PT.Adira Quantum Multifinance masih manual dalam pengisian aplikasinya yaitu dengan menggunakan proses catat mencatat, sehingga mempunyai banyak kendala seperti lambatnya proses pengajuan, dan pemasukan data kurang terkontrol, sehingga pihak analis lambat dalam mengambil suatu keputusan terutama dalam persetujuan kredit.

2. Dengan sistem pengajuan kredit yang berbasis web dapat menghasilkan informasi yang lebih cepat, data-data tersimpan dengan baik dan hasilnya lebih cepat, tepat dan efisien, sehingga dapat mengurangi data yang hilang dan proses pencarian datanya tidak memerlukan waktu lama terutama dalam persetujuan kredit.

3. Laporan yang dihasilkan saat ini data-datanya belum akurat karena sistem masih bersifat manual sehingga dapat menyebabkan (Human Error) atau kesalahan pada saat proses catat-mencatat pembiayaan barang.

\section{SARAN}

Agar penerapan sistem pengajuan kredit elektronik pada PT.Adira Quantum Multifinance ini dapat terwujud dengan baik, ada beberapa hal yang perlu diperhatikan yaitu:

1. Diperlukan pelatihan dalam penggunaan sistem yang baru kepada staff yang akan menggunakan aplikasi baru.

2. Perlu diadakan event-event yang rendah bunga kepada customer sehingga dalam pengajuan kredit elektronik tersebut meningkat.

3. Setelah sistem dapat diterapkan dan diimplementasikan dengan baik maka tidak menutup kemungkinan untuk dilakukan suatu pengembangan sistem yang baru, agar kekurangan pada sistem ini dapat diperbaiki maupun ditambah serta agar dapat tetap sejalan dengan perkembangan ilmu teknologi yang semakin canggih. 


\section{DAFTAR PUSTAKA}

1. Arikunto, Suharsimi, Prosedur Penelitian, Jakarta : Rineka Cipta, 1997.

2. Budi Irawan, Jaringan Komputer, Yogyakarta: Graha Ilmu, 2005.

3. E. Kristi Poerwandari,Pendekatan Kualitatif dalam Penelitian Psikologi, Jakarta : LPSP3 Fakultas Psikologi Universitas Indonesia, 1998.

4. Hanif Al Fatta, Analisis dan Perancangan Sistem Informasi, Yogyakarta : Andi, 2007.

5. Hartono,Prof. Dr.HM,MBA Jogiyanto, Analisis \& Design Sistem Informasi: Pendekatan Terstruktur Teori dan Praktek Aplikasi Bisnis Edisi Ke-3, Yogyakarta: Andi, 2005.

6. Kadir,Abdul,Pengenalan Sistem Informasi, Yogyakarta: Andi, 2003.

7. Keraf, Gorys, Tata Bahasa Rujukan Bahasa Indonesia : untuk Tingkat Pendidikan Menengah, Jakarta: PT.Grasindo, 1991.

8. Nawawi, H.Hadari \& Hadari, H.M.Martini, Instrumen Penelitian bidang sosial, Yogyakarta : Gajah Mada University Press, 1992.

9. Prabowo, H, Pengantar Antropologi, Jakarta : Gunadarma, 1996.

10. Wijaya, Hadi dan Rivai Wirasasmita, Analisa Kredit, Bandung: CV Pionir Jaya, 2000. 